\title{
Rereading and Studying on The Woman from Sarajevo (Gospodjica)
}

\author{
Li Pan \\ School of Foreign Languages, Sichuan University of Arts and Science, Dazhou, Sichuan, China
}

\begin{abstract}
The book The Woman from Sarajevo (Gospodjica) is one of the important novels written by Serbian writer Ivo Andric who once lived through the world war and worked in significant department of the country. This novel is not only the product of that period of time but also his only long psychological one which represents his interest in describing the mental states of the main characters. It is a purely psychological study of greed from the point of the pathology and obsession. It also shows his greatness in writing which helps him win the Nobel Prize in literature for his epic force of tracing themes and depicting human destinies drawn from the history of his country. This novel describes the real experience of a single woman named Raica Radakovic from a unique perspective, unfolding the ordinary people's life and fate in historical tide. It depicts Raica's life experience objectively, showing the author's philosophical reflection on people's life and fate, which makes this novel demonstrate its objective and profound artistic style.
\end{abstract}

Index Terms-The Woman from Sarajevo (Gospodjica), Raica, real life, philosophical reflection, profound style

\section{INTRODUCTION}

Serbian author Ivo Andric enjoys a high prestige in the world for his getting of the Nobel Prize in literature in 1961 and he is also the only one from Yugoslavia and even in the entire Balkan region to win this prize. In the middle of last century, the Chinese version of Ivo Andric's works was published in China. Since then, Chinese people got familiar with Ivo Andric and his works gradually, and Chinese researchers took interest in studying the man and his works. In 2012, Anka Lazarevic did comparative study between Lao She and Ivo Andric in his doctoral dissertation, which was the first comparative study between Ivo Andric's works and Chinese authors' works. Li Shimin once studied and published several papers about Ivo Andric and his works in journals at an earlier time. According to Li Shimin, Ivo Andric always related his writing with his homeland, described people's sufferings and their resistance to ethnic domination in blood and life, rightly criticized both the positive and the negative sides of people by revealing their temperament, their will, their flesh and their soul (1998). By reading his works, readers know that he strongly concerns the history and people's position in history. As a novelist, Andric was most interested in how the characters in his novels reacted to historical events; how they climbed to the peak of their dreams and how they behaved when falling from the peak (Li Shimin, 1997).

Even though, Ivo Andric's works were translated into Chinese and published in China early, they didn't draw too much attention from Chinese readers. The relevant research achievements were few; what's more, these findings were the rough introduction of Ivo Andric and his works, lacking systematic and in-depth research and evaluation on his literature works, which made it difficult to appreciate his achievement and charm in literature. For such a Serbian writer who won the Nobel Prize in literature in 1960s, his brilliance and permanent glamour are remained to be revealed and promoted. This paper is about to analyze and comment on his novel The Woman from Sarajevo(Gospodjica)in order that readers can appreciate Ivo Andric's great achievement and ability in shaping ordinary characters.

\section{THE ARTISTIC ACHIEVEMENTS OF THE NOVEL THE WOMAN FROM SARAJEVO (GOSPODJICA)}

The Woman from Sarajevo (Gospodjica), which is translated literally as Miss, is one of Ivo Andric's "Bosnian Trilogy"- three novels written by him from 1942 to 1944: The Bridge on the Drina (Na Drini cuprija), Bosnian Story(Travnicka hronika) and The Woman from Sarajevo(Gospodjica). The first two works-both of them chronicles rather than novels in the strict sense, dealt with Bosnia and her story like most of his other works and were regarded as his masterpieces, which fully demonstrated his broad vision and prominent ability in managing complex themes; in the third one, Andric presented present-day people and problems. He dealt with the psychology of the wealthy, with the war and postwar periods, and with the formation of a new society. It was his most unusual and least studied and was always considered to fail to exert his outstanding ability in narration. The Permanent Secretary of Swedish Academy Anders Osterlin didn't think highly of this novel, furthermore, he believed that Andric didn't exert his true talent- the talent in narrating in it even though he did quite well in characterization(Zheng Enbo, 1997). Such conception and evaluation was closely related to Andric's narrative perspective and obscure implied meaning. He preferred to evoke the overarching events of world history via the skewed perspective of the inhabitants of Western Balkans, a region marginalized throughout its history (Tihomir Brajovic, 2018). Andric did well in describing this region whose population is composed of different nationalities and religions and how people behaved when their interests and 
influences clashed.

In fact, Ivo Andric is not only a litterateur, a linguistics but also historian who concerns history and people's fate in different period, underlies his concerning in his writing. His personal experience and his strong interest towards history made his works deeply immerse in the slow stream of history, which also became his unique artistic achievement different from other writers'. He's good at making the artistic creation based on his study on large amount of historical materials. Even though the novel The Woman from Sarajevo (Gospodjica) was not a documentary fiction, it objectively depicted the social conditions in Sarajevo and Belgrade in the first half of the 20th century and told the story of the assassination of the Austrian Prince, the story of the fragment of history that little Serbia's fight against the mighty Austro-Hungarian empire and the history of the blood and tears of young Bosnians who were sent to serve (Li Shimin, 1998). Ivo Andric didn't write a period of real history but common people's life in general course of history. The war not only changed the fate of the whole nation, but also affected lots of ordinary people, changing the life trajectory and destiny of each person. In his novels, he displayed the history, the society and the people of different ages by describing their lives, their destinies, their sufferings and their wishes. Therefore, the experience and psychology of the characters in the novel are always arranged under such a big theme.

In the novel The Woman from Sarajevo (Gospodjica), Andric seemed to write about Raica's economic activities outwardly; in fact, he depicted the real economy form in World War I. The common phenomena of usury and hoarding during the war filled with ordinary people's lives. The good habits of diligence and frugality in traditional economy decayed while consumption was promoted in modern economy. On the face of it, Raica's strange economic activities were influenced by her father's last words to her though her father didn't find out the real reason for his bankruptcy. Actually, they were the relics of history; they were products of that period. This kind of arrangement was also the difference distinguishing this novel from Andric's other two famous ones which emphasized more on history and politics.

Indeed, The Bridge on the Drina(Na Drini cuprija) and Bosnian Story(Travnika hronika) embodied Andric's perfect epic literary achievements, while The Woman from Sarajevo(Gospodjica) just showed ordinary people's life and fate in major social changes, revealed people's plight caused by history and times. As his only long psychological novel The Woman from Sarajevo (Gospodjica), the heroine Raica's mental state is mostly caused by historical conditions without exception (Li Shimin, 1997).

If Andric emphasized the consciousness of a nation in the first two works, he stressed man's own destiny and freedom in The Woman from Sarajevo(Gospodica). The two different narrative perspectives formed two completely different aesthetic styles: one had great epic soul, the other had profound philosophic contemplation; one seemed grand and magnificent, the other seemed deep and calm; one showed the history of the Serbian nation, and the other showed the destiny of ordinary people in the historical trends. To some extent, The Woman from Sarajevo (Gospodjica) was not as great as the other two works, especially as for expressing the grand feeling, but it's obviously more profound in exploring life and value. Andric exhibited the relationship among ordinary people, society and the times by describing a woman's life and fate in the social unrest and changes. Its characteristic slant is underlined by the fact that the main character is a woman, cast by circumstances into the role of having to carry out what was traditionally regarded as men's work in the midst of the tumultuous and revolutionary events of the first third of the last century (Tihomir Brajovic, 2018, P87). From this angle, the work became deeper and more delicate rather than turbulent; and it was deeper and heavier rather than majestic. It didn't depend on magnificent historical events but the deep humanistic thinking towards struggles and fights to life yoke and freedom, the tangle between the darkness and brightness of human nature, the obsession between kindness and evil. From this perspective, no one would deny that the history of one country or one nation is as significant as one man's life, destiny and value; the latter one is also worth thinking and writing.

\section{RAICA'S LIFE AND FATE IN THE NOVEL THE WOMAN FROM SARAJEVO (GOSPODIJICA)}

Andric's quite objective narrative description in this novel made it fail to represent his common thinking towards life. The novel The Woman from Sarajevo (Gospodjica) began with the death of the old maid Raica Radakovic. Even though all major newspapers carried the news of her death in prominent position, together with the title to attract people's curiosity, they couldn't provide photos and details to stimulate people's imagination further, and then they didn't mention the death of the old woman any more. Andric arranged a beginning which seemed to cause suspect and guess, but he ended readers' imagination decisively, making this seemingly bizarre event return to its true nature: Raica's death was due to a heart attack. What's Raica like? Did she have an extraordinary life? Andric broke people's imagination again, saying whether she's alive or not, there's nothing to draw the attention and stimulate curiosity from the public (Gao Ren, 2017). Raica was one of the large number of ordinary people, who hadn't any great achievement when she was alive and was forgotten quickly after her death, unattractive. Andric told the readers that this was not a detective suspense novel full of bizarre stories and plots but a true experience of a common woman. Because of this, it didn't have legendary adventures or glorious careers, but ordinary daily life. What's worthy of the writer's concern and description in term of ordinary people's daily life and experience, especially about a strange and isolated old maid? For a woman, an old single woman, perhaps people were interested in her love stories. Andric disappointed readers once again because he didn't write Raica's colorful love stories and he even made Raica never fall in love with one man once, 
let alone arranged a marriage for her. Raica never laughed after her father died because her laughter was buried with her father. It is where Andric's ingeniousness and uniqueness lies. Adopting this tact made this novel escape from the routine of shaping the female as the theme, unique for its difference from the rest. Andric didn't portray Raica to be a beautiful and tender woman, not a pure and kind girl, but an average-looking woman who didn't focus too much on appearance or pay attention to the inner spiritual pursuit. What's worse, she's also an indifferent, eccentric and unsociable coward. Her monstrous behavior was not only for the sake of seeking money but for her mean manners to herself and her relatives in her life, for her meanness about money as well. For example, people believed that worn-out clothes and shoes should be thrown away, but for Raica, there's nothing bad enough to use and everything was useful. Then, she made enormous and irrepressible effort to mend and reuse them. The repaired shoes were too small and pressed and hurt her feet often, but she didn't mind it and called it the sweet pain and the delightful wound, letting the hurt feet hurt and itching wound itch (Gao Ren, 2017). She locked the cupboard and took the key with her after she found her mother and the acquaintance drank much coffee with sugar when the acquaintance came to see her mother. Raica and her mother lived simple and humble life like abstinent all the time: they had only one meal a day; they made a fire in one room; such examples were numerous to mention. She felt terribly ashamed to regard the moment of rest as wasting time pointlessly and to regard the swallow of bread as extravagance. In all, Raica lived an entire ascetic life filled with desolation and poverty. In order to accumulate money and wealth for ensuring that she would not fall into poor life, she forced herself not to spend any money, to mend everything, to economize and to endure instead of creating new wealth with her money. Can the phrases as "a slave to money" or "the miser" fully manifest the nature of her behavior and psychology?

\section{THE PHILOSOPHIC IMPLICATIONS IN THE NOVEL THE WOMAN FROM SARAJEVO (GOSPODJICA)}

In this novel, Raica had neither outstanding wisdom and courage, nor superior strength of character; she had neither noble moral consciousness, nor lofty ambition and great life goals. Her only goal in life was to accumulate money and kept herself out of poverty. Ironically, she accumulated money not to consume, but to economize; not to be extravagant, but to be consumption-restrained; not to live a better life, but to make her life be poorer and poorer. Instead of giving her the security she wanted, the wealth she accumulated became a burden on her life and eventually led to her death. On the contrary, Raica's uncle Vladimir Hagi-Wasich("Uncle Frodo") and the cheat in Belgrade Ratko Ratkovic lived a life of luxury and dissipation, even though they didn't have any money. Isn't it a thought-provoking phenomenon? Who can explain the value and destiny contained in it? Andric didn't point it out, didn't speak out but implied it between the lines. He didn't announce the answer superiorly, nor did he impose his thinking on the reader; he just described the phenomena in life and life itself objectively, leaving readers to think and contemplate. Actually, Andric revealed his emotion and tendency obscurely and subtly. If he's a doctor, he had no prescription for either Raica or his uncle. In fact, he had no prescription for the life itself. Even so, he managed to show some kind of sympathy and compassion for Raica's way of life. He created two glimmers of light in Raica's bleak and bitter life: one was her love for her father; the other was the smile and warmth in her childhood given by her extravagant Uncle Frodo who died young. It was the warmth in her memory that made her feel the mysterious love from that cheat in Belgrade Ratko Ratkovic who strongly resembled her uncle. These two glimpses, as faint as the glow of a firefly, shed light on the benign aspects of Raica's cold life. She was not a totally cold-hearted woman. However, the light was so faint that it went out completely at last. So, where is the light of life? What can help people to overcome the darkness of life? This is a question left by Andric, an eternal topic for thinking.

The religious love, the love between men and women and the moral love all disappeared in Raica's life and spirit, leaving only money, but money didn't bring her happiness and joy, but hardship, coldness and loneliness. Is it Andric's hint to people about the way of happiness? What can bring people the happiness in life and the peace in mind if material things can't? Andric didn't reveal the answer explicitly. Perhaps as there are a thousand Hamlets for a thousand readers, each people has a different answer to this question. Maybe that's what Andric intends to do and that's what makes him great. It is up to each individual to find the answer he or she needs. That's probably Andric's answer.

Of course, though this work The Woman from Sarajevo (Gospodjica) has different narrative perspective and style and the issues explored from the other two works, it still takes their cue from Andric's traditional literary technique and style: describing common people's life and fate in major historical events with objective style of writing to show the cruel and dark side of history and life. Outwardly, the story is a common rather than a fantastic one; the plot is flat without twists and turns; the narration is clam and objective instead of being humorous and lively and the language is plain without too many gorgeous words. That's why Andric's unusual intention can be explored. He deliberately describes the real, objective life and shows the true face of life in order to trigger readers' deep and constant thinking towards people's fate and the value and meaning of life. It makes the novel The Woman from Sarajevo (Gospodjica) become one of the great masterpieces and makes Andric be the writer as good as Tolstoy, Balzac, Dostoevsky and so on, deserving the fame of being one of the greatest writers undoubtedly.

\section{CONCLUSION}

All in all, Ivo Andric's The Woman from Sarajevo (Gospodjica) is a novel which focuses on the heroine Raica's daily 
life in Belgrade and Sarajevo. It really is a novel with ordinary rather than extraordinary stories, gentle but not tortuous plots, plain but not gorgeous language, calm and objective but not humorous and lively narration. In short, for the reader who likes adventures and excitements, they can't be attracted at the very beginning of reading this novel since they can't feel the urgency as strong enough to make the blood spurt. However, if you continue to read it quietly, you will be attracted unconsciously; you will be moved by the simple words and the deep thinking between the lines. Like olives, you will know the endless taste only after chewing it carefully and thoroughly. The ups and downs of history, the upheavals of politics, the complexity of society, the noise and indifference of the world and the bitterness and sadness of life all rise and fall between writers' words. Ivo Andric's works are like the sea which seems calm and tranquil on the surface, however, there are the surging undercurrent hiding in the recesses of apparent calmness which can always pull readers' thoughts, provoke their contemplation and stir the nerves of their heart and soul. It appears to be a babbling stream, but the sound of it is often loud enough to strike your ears and heart.

In this novel, there is no preach and comment based on moral high ground and it doesn't reveal the writer's conception of value and yardstick of judgment. This is almost impossible for many writers. Although the woman in the novel is dissocial, hardhearted, indifferent, selfish and inhuman, she's not always criticized but sympathized by readers.

History is often created and changed by ordinary people, at the same time, it is also wrapped by the times and unable to be independent, unable to obtain complete freedom. Sarajevo Assassination was a political event caused by an unknown young man, but it eventually resulted in a social and political revolution around the world. It was the event that triggered a social shock, political and economic reform, and thus changed the lives and destinies of millions of people in the world. The novel shows the fate of an ordinary person in the tide of changing times and political events. Raica is only one of those, representing the fate of thousands of Serbs and changes in their lives.

Everyone wants to take control of his own life and overcome the fated hardships, dangers and failure in it. As a result of witnessing her father's death, Raica stuck to controlling her own destiny and life alone and avoided being influenced by anyone or any event outside all the time. So she's always alone and remained aloof, breaking off all social contact with other people and living like a rat. Eventually, she was torn apart by the outside events, forcing her to move from Sarajevo to Belgrade. Even worse, she lost the money which was regarded as a guarantee for her because she was deceived by a cheat who took after her uncle very much. At last, she died of terror because she firmly believed that a stranger broke into her room.

Whether it's the pain or love, it will dissipate and be forgotten one day. Raica loved her father so much, but he was gone and left behind forever. Her mother who always accompanied with her was also forgotten. Her life and death would be forgotten soon, too. Life is always relentless and it will bury everything gradually. The author believed that she had no future while her past has already been buried (Gao Ren, 2017). The "present" is what she only has, but she feels so lonely, so poor, so isolated and so scared. The anguish and struggle in Raica's spirit makes readers feel a kind of deep sadness.

Ivo Andric once said that we should draw a foreshadowing of the present when describing the past. We would encounter similar phenomena and the same problems in the facts of the past and the present. (Zheng Enbo, 1997) That's true! The destiny of history and individuals, the relationship between the individual and the group and the independence and freedom of the individual revealed in the novel The Woman from Sarajevo(Gospodjica) are the questions which people are still continuing to think about, aren't they? In fact, these questions are the eternal themes for human being.

Ivo Andric's greatness lies in this. He often uncovers the relationship among man's destiny, history, society and human group by describing the ups and downs, joys and sorrows of lots of general characters. There is no such thing as being great or small; being noble or despicable; there's no separation or integration; no fraud or sincerity; no passion or indifference; no loyalty or deception. The value and meaning of life, life and dreams, money and happiness as well as extravagance and poverty constitute the universal life of mankind. This is exactly the reality of life, the reality of human destiny. Is there any writer who can present the real life and destiny of human being in such a truthful, objective and unassuming way? Maybe Ivo Andric is surpassed by several writers in terms of literary skills and means, but Ivo Andric is unique in his calmness and objectivity, in his insight into human life, in his realistic representation of human destiny and his ability to judge no character from a moral high ground. It is in his plain and emotive language, in his cold and sympathetic tone that he expresses his thoughts, his concerns, his understanding and his sympathy for the common destiny of mankind.

Perhaps this is the value and significance of rereading and studying Ivo Andric and his works today.

\section{REFERENCES}

[1] Andric, I. (1945). The Woman from Sarajevo (Gao Ren, Trans.). Shanghai: Shanghai Literature and Art Publishing House.

[2] Brajovic, T. (2018). A Paradoxical Critique of Liberalism in the Novel The Woman from Sarajevo by Ivo Andric. Journal of the North American Society for Serbian Studies, 29, 87-92.

[3] Li, S. M. (1997). People and History in Andric's Works (I). Dongou, 2, 36-40.

[4] Li, S. M. (1997). People and History in Andric's Works (II). Dongou, 3, 27-30.

[5] Li, S. M. (1998). Andric and His Hometown. Dongou, 2, 59-61.

[6] Zheng, E. B. (1997). The World Pride Belongs to Him-Excerpt from The Biography of Ivo Andric. Dongou, 4, 29-33. 
Li Pan, a visiting scholar in U.S., is currently a lecturer in the School of Foreign Languages, Sichuan University of Arts and Science, Sichuan, China. Her research interests include Foreign Language Teaching and Literature. 